\title{
SITTING IN JUDGMENT - THE WORKING LIVES OF JUDGES
}

\author{
JCR Circle Seminar Monday 14 November 2016, Bar-Ilan University \\ Professor Penny Darbyshire, Kingston University, London p.darbyshire@kingston.ac.uk
}

Abstract: Penny will describe the work-shadowing method she used in her penetrating study of the work of all types of judge in England and Wales. She will give a summary of her findings with especial reference to case management, plea negotiation and case settlement.

Sources: $\quad$ Sitting in Judgment - the working lives of judges (Oxford, Hart 2011) (SIJ) Darbyshire on the English Legal System, $11^{\text {th }}$ ed (London, Sweet \& Maxwell 2014), see especially the chapters on civil and criminal procedure, and ADR. "Judicial Case Management in Ten Crown Courts" [2014] Criminal Law Review 30

"Transparency in Getting the Accused to Plead Guilty Early", a case note on Goodyear (Practice Note) [2005] EWCA Crim 888, at [2006] Cambridge Law Journal

"The Mischief of Plea Bargaining and Sentencing Rewards" [2000] Criminal Law Review 895.

The book, Sitting in Judgment reports the findings of research from 2003-2010 on the working lives of judges.

The aims were very general indeed: to find out what judges did and what they were like.

\section{Method}

I work-shadowed 40 Baby Boomer judges in the family, crime and civil courts throughout England and Wales, in a very broad span of their work, from district judges up to the UK Supreme Court. I interviewed them and 37 more judges for about 1.5 hours. I met hundreds more, in my travels. I spent the whole working day with each judge for four days in a variety of their work, often spread out over time. I travelled on circuit with the High Court judges and I was permitted to observe Court of Appeal deliberations. I had unlimited access to information: all the case papers and reports, and support by the Lord Chief Justice. I was with each research judge throughout their working day, on the bench or in their room. I encouraged them to think out loud about their work. This project is unique. I used this technique before, in my PhD in the 1970s, with magistrates' legal advisers. In 2012, I did a small project investigating judicial Crown Court (criminal) case management, published in 2014.

\section{Civil cases}

Civil procedure is explained in ch 10 of my textbook and ADR in ch 12. The emphasis of the Civil Procedure Rules 1998 is on proactive judicial case management in pre-trial procedure, with a view to encouraging settlement or ADR, narrowing the trial issues or avoiding trial, and speeding the case along, using a proportionate amount of resources. Civil trials have generally declined since 1990 . About $80 \%$ of cases are small claims and most civil cases are handled by district judges. I watched civil trials in the county court and High Court, and civil appeals in the Court of Appeal and UKSC.

\section{My civil court findings in Sitting in Judgment}

- The judges loved their work, especially achieving fair outcomes.

- Beforehand, I thought civil courts were full of rich people asserting property rights but I found they are crowded with the dispossessed, with multiple civil problems.

- Litigants in person are very prevalent. Judges were not trained to help them until about 2005, when judgecraft classes were offered, but they were generally very 
empathetic and good at translating into plain language. The most obvious quality of almost all judges was astonishing patience and great listening skills. Judges said they had been radicalised as lawyers or judges by the social problems they encountered in the courts. They were enraged by cutbacks in legal aid and court help-desks, and problems like homelessness, the treatment of asylum seekers, child abuse and social security delays.

- The settlement rate was extremely high. For example, one day, all 17 scheduled High Court cases settled. As another example, most small claims settled. In Central London County Court, one week there was no trial work for the circuit judges, who would normally hear substantial civil trials. Because of "the vanishing trial", pre-trial case management takes on importance. This was done by district judges in "boxwork" and phone conferences. (Case management software was useless). Much of this is meant to be handled electronically now.

- Judges experimented with ADR, generally from 1990, but much earlier in respect of arbitration and family mediation and arbitration in the Commercial Court. For instance, in one county court all district judges sat as mediators on Wednesdays. In Central London County Court the default service was/is mediation.

- The county courts were extremely shabby and understaffed; help desks were limited; judges did all their own typing and orders. They swapped case management templates online.

- In the High Court, the 12 Commercial Court judges insisted on doing all their own case management, on Fridays. This court has always emphasised pro-active management. Parts of cases will be hived off into ADR/arbitration with the judge keeping the central issues.

\section{Family Cases}

I was a stranger to family courts. Since my research, there is now one unified family court, since 2014. Governments have been heavily criticised since 2010 for massive cutbacks in legal aid since 2012 (see chapter 17 of my 2014 textbook). Now, parties cannot get legal aid for private law disputes unless there is an allegation of violence. This has had the unintended consequence of reducing the number of couples opting for mediation, as they have no lawyer to encourage it! The Family Court Procedure Rules and Practice Directions are here: http://www.justice.gov.uk/courts/procedure-rules/family/rules pd menu

\section{My family court research findings from Sitting in Judgment}

- Children cases are multi-party and multi-layered.

- Judges took on a proactive and inquisitorial role, ferociously focused on the interests of the child and sometimes reaching an orchestrated settlement that no-one else had argued for. They had to be peacemakers with "parents behaving [very] badly".

- I never heard any law cited in 57 days of research, including in the Court of Appeal.

- Family courts have their own culture, judges and lawyers. Outsider judges called them "tree huggers" and "babysitters".

- All judges in private law child or money cases insisted on making people negotiate outside the courtroom. One judge operated a "shuttle service" with multiple sets of parents. Judges pleaded with people to settle, especially in poor households splitting meagre resources. In the Central Family Court, judges offered conciliation.

\section{Criminal courts}

Criminal procedure is described in ch 12 of my textbook. Most work $(84 \%+)$ is handled by lay justices in magistrates' courts, making the English legal system unique, worldwide. As with civil cases, work has shifted down onto the lower courts. I commented on this at [1997] Crim LR 627. Serious business is handled by professional magistrates and there is research contrasting lay and professional magistrates. I am fairly expert in criminal procedure and have researched and written about juries, magistrates and plea bargaining. In the past, I 
have expressed concern about adopting American style plea bargaining (PB) (2000, above).

Since then, we have introduced contractual bargaining and contractual immunity in organised crime. I wrote the case note about the Goodyear practice direction which lays down the rules on $\mathrm{PB}$.

\section{Criminal court research findings from Sitting in Judgment}

- The youth court had lots of serious business, out of sight and out of mind. Since 2015 they will have more BUT very few juveniles now come to court.

- Crown Court circuit judges were very happy at work.

- Circuit judges spent most of their time trying to move cases along.

- I thought this story was apocryphal but there really is a culture of plea bargaining in the northern and north-eastern circuits. Judges were brought up in it, as lawyers. They often spent most of the day outside the court room but did not participate in negotiations. Trials countrywide were very fragile and not one proceeded smoothly and as scheduled.

\section{Research on judicial criminal case management (2014)}

In 2005, proactive judicial case management was introduced, in the new Criminal Procedure Rules, copying civil procedure. Disobedient lawyers can be punished. In 2012, I visited 10 Crown Courts throughout England and Wales. My aim was to learn about and compare different case management regimes and judicial styles. I observed case management with each resident (managing) judge and one other. I interviewed them.

\section{Research findings}

- Different court regimes. e.g. Gold Court had a pre-trial review (PTR) in every case. Some judges were well-known nationally, e.g. 'Mad Harry' who 'cracked' cases.

- Judges differ. At each court there was a difference in court style between judges, e.g. Silver Court. Judges generally disagreed on principles, e.g. defence statements, and tactics e.g. Goodyear sentence indications (e.g. Orange Court debate); Judges Indigo 2 and Indigo 3 were trying to import practices and culture from their former courts 'we were much more robust in the Midlands'. Judges changed their own attitudes: Resident Violet changed his plea and case management (PCMH) approach and listing regime radically, in 2007. Some judges were 'on a mission': Judge Gold 3, from a civil background, repeatedly punished lawyers for disobeying criminal case management orders.

- Criminal Procedure Rules were 'irrelevant' in some courts. Interesting question: what is a rule? A practice?

- Did CPRules effect a "complete culture change", as intended? 1 judge said yes, 14 said no, 2 said 'it's starting'.

- Culture had changed everywhere but maybe not by Crimpro Rules.

- Cracked trials had not reduced since 2006 but were not seen as a bad thing by judges.

- There were no virtual Plea and Case Management Hearings. Video-PCMHs had limitations: getting a plea; signing defence statement. (But see reforms from 2016)

- PCMH form was criticised as too long, Resident Yellow: 'a frightening waste of public money', Black etc used checklist, Resident Court used their own electronic template; Judge Indigo 3 and Judge Gold 3 asked for electronic templates. Some courts used additional forms, e.g. for s.51 hearings.

- Defence statements had markedly expanded since the research for Sitting in Judgment. Some were formulaic, demanding. The purpose is to stop ambush by the defence. I suggested (research for the Auld Criminal Courts Review 2001) they could help the jury.

- Costs were seldom imposed. Judges preferred the 'Naughty Boys Court'. Some courts were notorious. Gold 3 didn't understand effects of his penalties on lawyers.

- 13 of 17 judges noted no culture change in prosecution disclosure. Judges were strikingly concerned: Resident Yellow, 'The CPS depresses me'; Resident Silver, 
'The CPS is driving me to suicide'. Judge Indigo 2, ex-CPS manager, 'it frightens me'. Judge Gold 2, 'We've gone backwards'.

- Very different attitudes to Goodyear applications.

- North south divide. N perceived SE as poor managers. Orange/Yellow/Green 'We're suffering'

- Early Guilty Plea scheme criticised, delaying process, e.g. yellow, green, blue, underused.

- Training DVD, depicting strict case management was criticised: 'not real life', 'people were shocked', 'unrealistic'.

\section{Research Conclusions}

- Judges could learn great lessons from one another, especially oldest regimes, e.g. Yellow. Resident Yellow documented how he changed culture. Info was not captured. He retired in 2013. Nobody captured/copied previous electronic traffic light scheme at Orange Court.

- Could use an internet portal. Copy Advocates' Gateway. County court (civil) district judges have invented and circulated electronic case management templates since pre-2000. (3 circuit judges in my book used to be district judges).

- Non-resident judges should be included in discussion. Some anorack-judges have good ideas, eg Judge Indigo 2 (management expert) and Judge Orange 3. Judges Violet 2 and 3 had case management jobs.

\section{Latest News on Criminal Case Management}

Lord Justice Leveson's Review of Efficiency in the Criminal Courts 2015

https://www.judiciary.gov.uk/wp-content/uploads/2015/01/review-of-efficiency-in-criminalproceedings-20151.pdf recommended

- A statutory duty of case ownership; with all parties adding to the online case file

- Audio and video hearings pre-trial

- Early presentation of evidence, digitally

- Robust and consistent case management by magistrates and judges

- Ground rules arrangements for all vulnerable witnesses

- 'Route to verdict' jury directions and reducing the judge's summing up

- Implementing the CJS common platform for case management

The latest policy statement on digitisation is Transforming Our Justice System 2016 by the Lord Chancellor (Minister of Justice), Lord Chief Justice and Head of Tribunals.

https://www.gov.uk/government/uploads/system/uploads/attachment data/file/553261/jointvision-statement.pdf

'Over time, the work of the courts and tribunals will use online, virtual and traditional hearings as best meets the circumstances of the case. As new technologies bed down, we anticipate that more and more cases or parts of cases will be carried out virtually or online.'

There is a case management reform Blog and newsletters by email. https://www.judiciary.gov.uk/subject/better-case-management-bcm/ 